Tyranny Lessons 
O F H A W I' I

PRES S

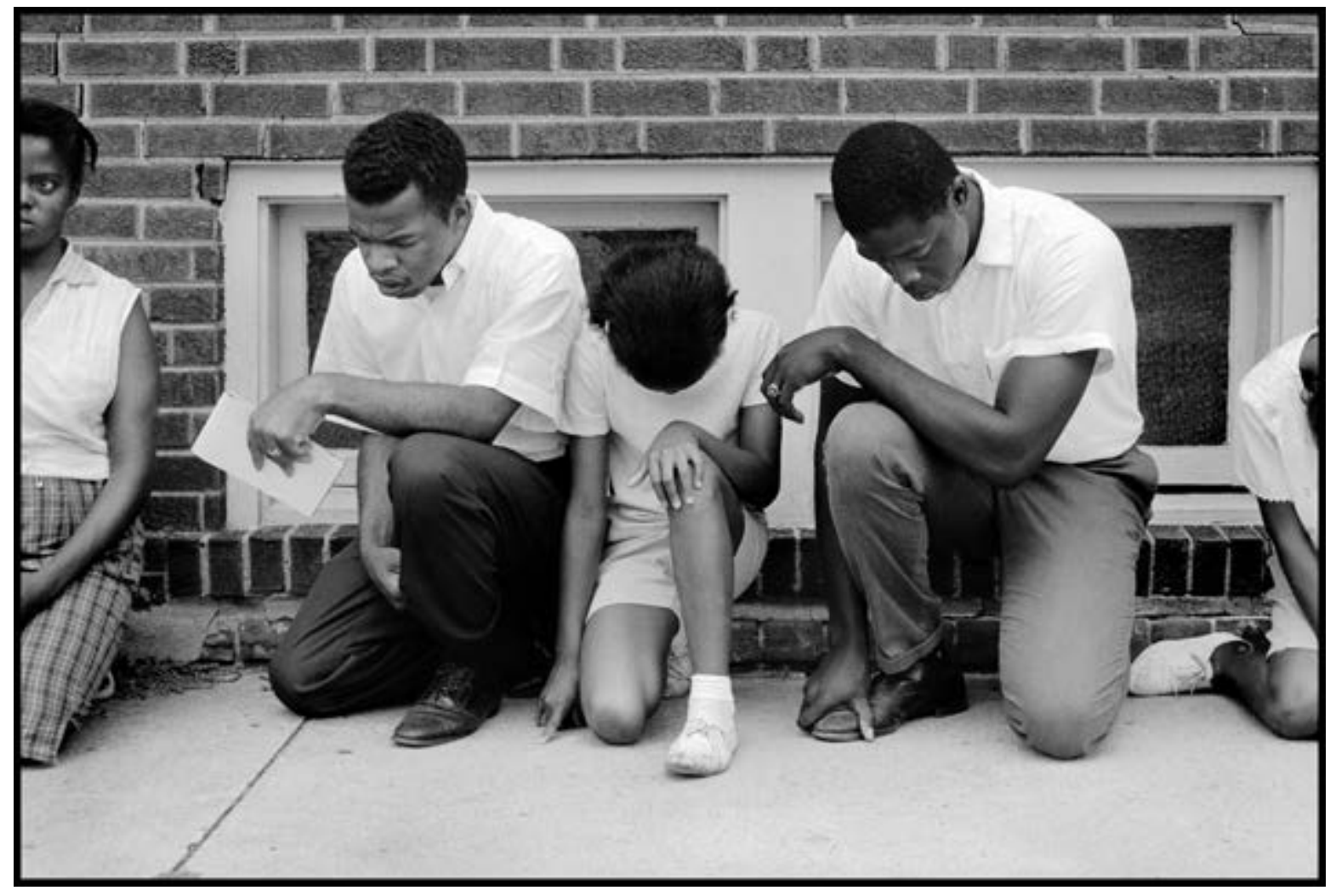




\title{
Tyranny Lessons
}

I NTERNATIONALPROSE, POETRY,

A N D PERFORMANCE

\section{Frank Stewart}

SERIES EDITOR

\author{
Alok Bhalla \\ Ming Di \\ GUESTEDITORS
}

Cairo, Illinois, 1962.

John Lewis (second from left)

and other protestors at Cairo's whites-only pool.

๑ Danny Lyon/Magnum Photos 


\section{Mānoa: A Pacific Journal of International Writing}

Editor Frank Stewart

Managing Editor Pat Matsueda

Associate Editor Noah Perales-Estoesta

Staff Silvana Mae Bautista

Designer and Art Editor Barbara Pope

Consulting Editors

Anna Badkhen, Robert Bringhurst, Barry Lopez, W. S. Merwin (1927-2019), Carol Moldaw, Michael Nye, Naomi Shihab Nye, Gary Snyder, Julia Steele, Arthur Sze, Michelle Yeh

Corresponding Editors for Asia and the Pacific

CAMBodia Sharon May

China Chen Zeping, Karen Gernant, Ming Di

HONG KONG Shirley Geok-lin Lim

INDONESIA John H. McGlynn

JAPAN Leza Lowitz

KOREA Bruce Fulton

NEW ZEALAND AND South PACific Vilsoni Hereniko, Alexander Mawyer

pacific latin america Noah Perales-Estoesta

philippines Alfred A. Yuson

south Asia Alok Bhalla, Sukrita Paul Kumar

WESTERn CANADA Trevor Carolan

Advisors Laura E. Lyons, Robert Shapard

Founded in 1988 by Robert Shapard and Frank Stewart

Mānoa is published twice a year and is available in print and online for both individuals and institutions. Subscribe at https://www.uhpress.hawaii.edu/title/manoa/. Please visit http://muse.jhu.edu/journals/manoa to browse issues and tables of contents online.

Claims for non-receipt of issues will be honored if claim is made within 180 days of the month of publication. Thereafter, the regular back-issue rate will be charged for replacement. Inquiries are received at uhpjourn@hawaii.edu or by phone at 1-888-UHPRESS or 808-956-8833.

Mānoa gratefully acknowledges the support of the University of Hawai' $i$ and the University of Hawai' $i$ College of Languages, Linguistics, and Literature; with additional support from the Community of Literary Magazines and Presses, the Amazon Literary Partnership, and the Mānoa Foundation.

manoa.hawaii.edu/manoajournal uhpress.hawaii.edu/title/manoa/ muse.jhu.edu

jstor.org 